\title{
An analysis of Saudi Banks' Disclosures inCompliance with BASEL III Norms: A Case study of Saudi Bank Fransi
}

\author{
Sultan A. Al-Bogami \\ Dean - College of Business and Associate Professor (Accounting) - College of Shariah, Umm Al-Qura \\ University, Makkah Al-Mukarramah, Saudi Arabia.
}

\begin{abstract}
: basel iii places stricter norms for the banks in terms of capital adequacy and risk management in order to overcome any type of financial crisis. The reforms include changes at the macro level and at the individual bank level. The complete implementation of the full set of reforms has been scheduled to 2019. However, the banks need to comply with and make arrangements to comply with the new standards. The banking system in saudi arabia, monitored by saudi arabian monetary agency, has been actively trying to enforce the reforms as per the agreed timelines. So far, the agency has introduced the leverage, liquidity and capital adequacy ratios. A sample of banks will be studied in detail for their compliance with the new norms. The results will be of significance to the banks as well as the regulator to assess the current state of compliance. Further the banks in other countries of the region will also benefit from the findings of the study.
\end{abstract}

Keywords: banking; regulation and supervision, basel iii, saudi arabian monetary system

\section{Introduction}

The Basel Committee on Banking Supervision (BCBS) published new regulations for the banks in light of the financial crisis that touched the entire world. It is strongly felt that although the core principles and Basel III framework have been adopted by the member countries, the actual implementation will be divergent. Though the deadline for the full compliance is 2019 , there is a need to keep things in order in advance. The direct impact of the new regulation is mainly on the capital held by the banks. The new regulations require new types of 'capital buffers'. In general, the Basel III norms comprise of three main elements namely, "higher capital ratios, better capital quality and stricter liquidity requirements". It is remarkable to note that the banks in Saudi Arabia and many other Middle Eastern countries always maintained a high capital adequacy ratio and were less exposed to risk. This enabled them to achieve the compliance required by Basel III. This study focuses on the unit level compliance because Basel provides its recommendations to the central banks but the actual implementation has to be executed by the banks. The study will study three different banks for a complete assessment of the compliance. However, at this stage the results of one bank is presented in this study. The assessment has been done entirely on the disclosures available on the different online resources. At the advanced stage of this study, multiple sources of information will be checked to ensure that there is no discrepancy in the disclosures.

\section{Historical Overview}

Basel Committee got its name for the reason that the first meeting of governors of central banks to discuss the banking regulation was held at Basel, Switzerland in 1974 (Batainah 2014) Currently, the Committee has twenty seven members. The main aim of the Committee was to promote a uniform set of rules for the calculation of capital adequacy in order to ensure a stable banking system at the global level. A historical evolution of the Basel has been presented in the Fig 1.

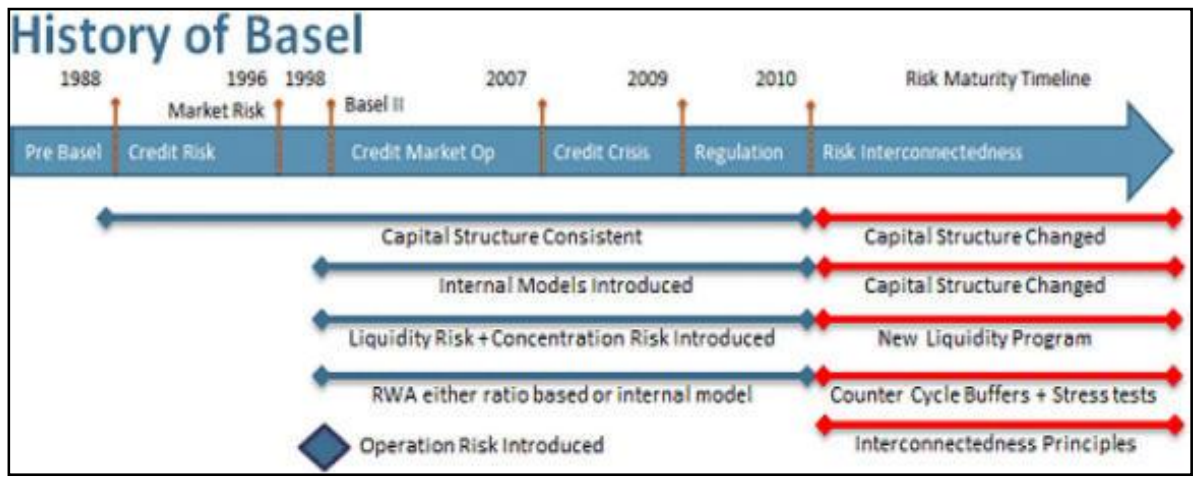

Figure 1 History of Basel (Vousinas2015) 
The main impetus in the first set of norms, called Basel I, was on capital adequacy, competition and consideration of risk. Additionally, the Committee also addressed the supervision by the central banks. In the initial stage, the provision of capital was called "the rule of 8 percent". The Basel II was an improvement upon the norms laid down in Basel I. In the new norms, three pillars were established to manage the risk emerging from the operations of the bank. These pillars were called the Capital Requirements, Supervisory Review Process, and Market Discipline. The first pillar comprised of the capital requirements based on the credit, operational and market risks. The second pillar resulted in the formation of Internal Capital Adequacy Assessment (ICAAP) to provide the regulatory framework as well as considering new types of risks. The third pillar deals with raising the minimum capital requirements and the supervisory review process. This requires information exchange among banks and also with other stakeholders. This requires the banks to disclose details of their "financial exposures, risk assessment process and capital adequacy ratios." Finally, after the major financial crisis, the Basel Committee proposed new set of regulations in all the three pillars and added another standard. This was called the Basel III.

\section{Basel III}

Basel III was approved by the Basel Committee in the G-20 summit held in Seoul in 2010. The main focus of the new norms were enhancing the resilience of the banks and facing the shocks (KPMG 2011). In order to achieve these two major objectives, the Committee sought to modify mainly the capital adequacy requirements. There are now new requirements for increased paid-up capital. Further the quality of banking has also been addressed in the new norms. Overall, Basel III proposes reforms in three main areas - Capital; Liquidity; General Stability. At the background of these proposed reforms is that the banks become more capable of withstanding the periods of deep recession or other financial or economic shocks. Hazarika and Dubey (2014) provided a detailed analysis of the state of implementation and impact of Basel III on emerging markets, Europe and the US. Aosaki (2013) also explain the challenges for Japan, USA, and the European Union in the implementation of Basel III.

\subsection{Reforms}

The Basel III framework includes the three pillars and an additional standard on liquidity management. The main areas of reforms proposed by Basel III are summarized in Figure 2 .

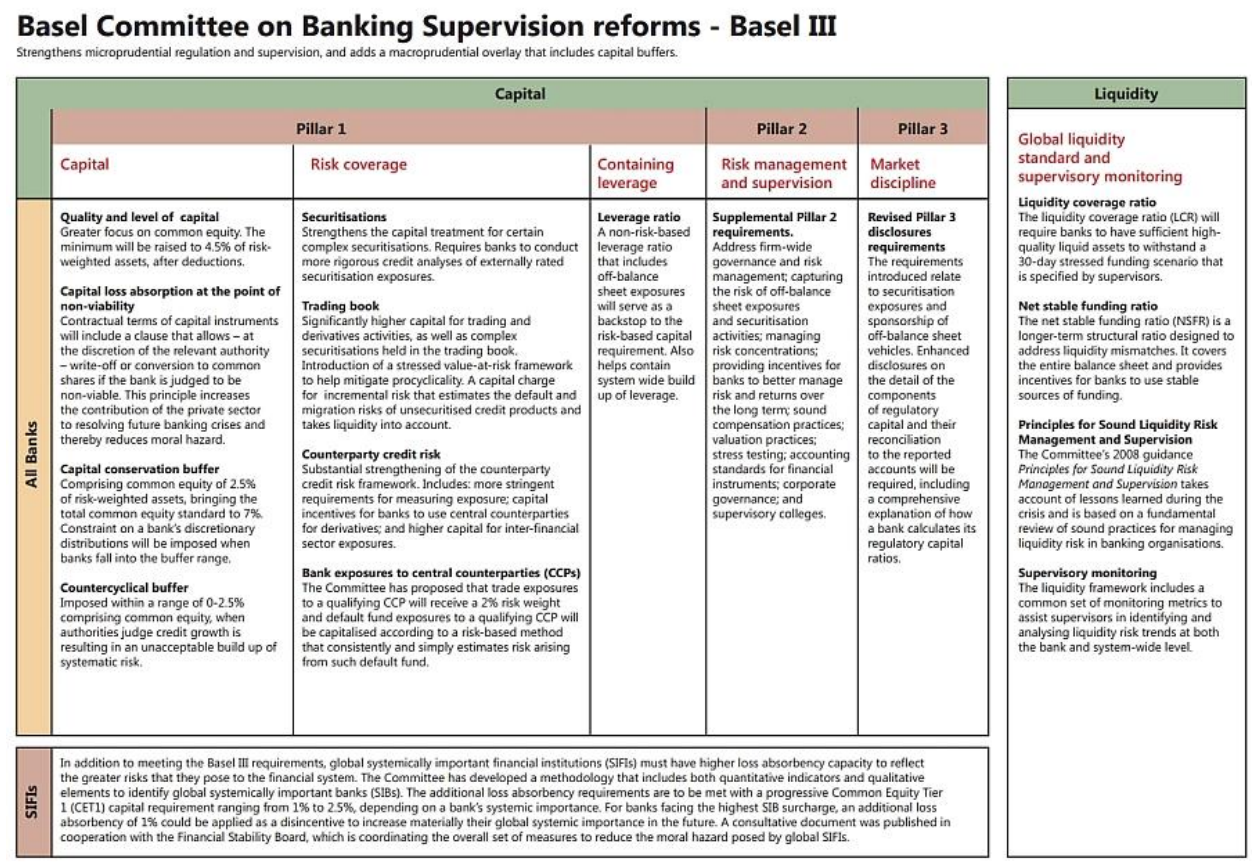

Figure 2 Summary of Reforms in Basel IIISource: BIS (2011)

\section{Pillar 1 - Capital Requirements}

This pillar in Basel III comprises of three major areas namely the capital adequacy; risk coverage and market discipline (BIS 2011). Pillar 1 of the Basel III Accord, as adopted and implemented by SAMA, covers the minimum regulatory capital requirement that a bank is expected to maintain to cover credit, market and operational risks stemming from its business operations. 


\section{a. Capital}

Basel III proposes increased significance of common equity and the minimum requirement has been set as $4.5 \%$ of the RWAs (risk-weighted assets). There will be a clause for the inclusion of capital instruments that would require a relevant authority to convert them into common shares in case the bank becomes nonviable. In this way, the private sector will play an increased role in bailing off the banks in times of crisis. There is a new requirement of capital conservation buffer in the form of common equity that must be $2.5 \%$ of the riskweighted assets. Another provision of counter cyclical buffer has been imposed that comprises of $0-2.5 \%$ at the discretion of the authorities. the capital ratio Tier 1 has been increased from 4 to $6 \%$. The minimum capital requirements has to be more than $8 \%$. the capital structure required as per Basel III is summarised in Table . The constituents of Tier 1 capital are the common shares, minority interests, and retained earnings. Since January 2013, the banks are required phase-out those instruments that do not meet the criterion.

Table 1 Basel III Capital Structure

\begin{tabular}{|l|l|}
\hline Common Equity & $\%$ \\
\hline Minimum & 4.50 \\
\hline Stabilizing & 2.50 \\
\hline Total Required & 7.0 \\
\hline Tier 1 Capital & \\
\hline Minimum & 6 \\
\hline Total Required & 8.50 \\
\hline Total Capital & \\
\hline Minimum & 8 \\
\hline Total Required & 10.50 \\
\hline
\end{tabular}

Source: Adapted from Vousinas (2015)

\section{b. Risk Coverage}

Another constituent of Pillar 1 is the risk coverage that requires banks to undergo strict analyses of externally rated securitisation exposures. Schwerter (2011) describes in detail how the Basel III standards will help in greater mitigation of the risks. The banks are required to maintain higher capital for trading and derivatives activities. The norms introduce a value at risk framework for mitigating the incidence of procyclicality. There is also the introduction of a capital charge for the excess risk for the unsecuritised credit products. The counterparty credit risk framework established by Basel III requires stringent measurement of exposure, incentives for central counterparties and higher capital required for the exposure in the inter-financial sectors. The Committee has also proposed details on the capitalisation of trade exposures to a qualifying central counter parties. Equity risk has also been covered in this element of Pillar 1.

\section{c. Containing Leverage}

Basel III requires the enforcement of the leverage ratio for the banks. It is proposed that a leverage ratio of 3\% implying that the ratio of capital to total assets should exceed this limit. The new ratios related to leverage and liquidity propose a non-risk-based measurement in order to maintain adequate capital in times of stress. Liquidity coverage ratio has been introduced that aims to measure the unencumbered assets of the banks (BIS 2010). Another advantage of the leverage ratio is to reduce the lending limit of the banks.

\section{Pillar 2: Risk Management and Supervision}

The Basel III propose that this pillar should address " Address firm-wide governance and risk management; capturing the risk of off-balance sheet exposures and securitization activities; managing risk concentrations; providing incentives for banks to better manage risk and returns over the long term; sound compensation practices; valuation practices; stress testing; accounting standards for financial instruments; corporate governance; and supervisory colleges". The pillar also includes the supervisory review process called the Internal Capital Adequacy Assessment (ICAAP). There should be the credit assessment by external credit rating agencies (CRA). The detailed qualifications of the CRA have also been stipulated by Basel III.

\section{Pillar 3: Market Discipline}

This pillar deals with the transparency by the banking institutions. The transparency must exist in the "capital structures, risk exposures, risk mitigation and the risk management process". The new norms require disclosures related to securitisation, sponsor of off-balance sheet vehicles, components of regulatory capital, and details of the calculation of capital ratios.

\section{Liquidity and Supervision}

Basel III proposed detailed regulations called "Global liquidity standard and supervisory monitoring". The Basel document describes the role of liquidity coverage ratio. This standard aims to ensure 
that a bank maintains an adequate level of "unencumbered, high-quality liquid assets" so that the bank can have adequate reserve for 30 days. The Committee assumes that a bank may be able to implement corrective action within this period. For this purpose, two main ratios have been recommended by Basel III. These ratios areLiquidity Coverage Ratio (sufficient high quality liquid assets) and Net Stable Funding Ratio (for managing liquidity mismatches). The liquidity framework also imposes a set of monitoring metrics to supervise the liquidity risk at the bank and system level.

\section{Basel IIIAnd Saudi Banking Sector}

Saudi Arabia along with many other countries in the Middle East are implementing the Basel III regulations (Diemers, et al 2014). Saudi Arabia is the only member in the Basel Committee from the Middle East. The central bank of Saudi Arabia, Saudi Arabian Monetary Agency (SAMA) is the first central bank in the region to meet the capital adequacy as early as in 1966. As a member of the Basel Committee, SAMA has been actively involved in developing these standards and it fully supports the package of reforms announced by the BCBS. Basel I and Basel II were adopted in 2002 and 2008 respectively. SAMA has also issued the framework and guidelines for the implementation of Basel III. The final rules related to risk-base capital were issued in December 2012. IMF (2013) provides an assessment of the supervisory structure in Saudi Arabia. The Saudi central bank has always encouraged the banks to keep higher capital adequacy resulting in a high capital adequacy ratio of $18-20 \%$ by many banks. In fact there are several areas where SAMA adopts a stricter approach. A comprehensive assessment of the compliance of Saudi Banks with Basel III was undertaken by the Bank for International Settlements (BIS 2015). The report of this assessment called the Regulatory Consistency Assessment Programme (RCAP) provides the detailed status of compliance of the banks with each pillar and their constituents. It was reported that the banks in Saudi Arabia comply with the Basel III standards. The RCAP reported that several elements of Basel capital framework had not been adopted till the report was completed. It was observed that the $85 \%$ of the banks' regulatory capital is composed of Common Equity Tier 1 (CET 1).

\subsection{About the bank}

\section{Case Of Banque Saudi Fransi}

Banque Saudi Fransi (BSF the Bank) is a Saudi Joint Stock Company established by Royal Decree No. M/23 dated Jumada Al Thani 17, 1397H (corresponding to June 4, 1977). The Bank formally commenced its activities on Muharram 1, 1398H (corresponding to December 11, 1977), by taking over the operations of the Banque de l'Indochineet de Suez in the Kingdom of Saudi Arabia. The bank has a total of 82 branches. The bank has an active supervisory board that looks after its shariah compliance. The BSF group comprises of several entities fully owned and some partially owned. The wholly owned entities are Saudi Fransi Capital, Saudi Fransi Leasing, Saudi Fransi Insurance Agency, and Sofinco Saudi Fransi. The group has minority investments in Banque BEMO Saudi Fransi, Banque BEMO, and Saudi Fransi Cooperative Insurance Company.

\subsection{Financial Condition}

The bank prepares its financial statements in accordance with the Accounting Standards for Financial Institutions promulgated by the Saudi Arabian Monetary Agency (SAMA) and International Financial Reporting Standards (IFRS). The Bank prepares its consolidated financial statements to comply with the requirements of Banking Control Law and the Regulations for Companies in the Kingdom of Saudi Arabia. The authorised, issued and fully paid share capital of the Bank consists of 1,205.3 million shares of SAR 10 each (Source). The ownership structure of the bank is presented in Table 2.

Table 2 Ownership of Bank's share capital

\begin{tabular}{|l|l|l|l|}
\hline SAR '000 & $\%$ & 2014 & 2013 \\
\hline Saudi shareholders & 68.9 & $8,303,572$ & 6227,679 \\
Credit Agricole Corporate and Investment Bank & 31.1 & $3,750,000$ & $2,812,500$ \\
(CA-CIB) & & & \\
Total & & & \\
& & & \\
\cline { 2 - 4 } & 100 & $12,053,572$ & $9,040,179$ \\
\hline
\end{tabular}

The capital structure of the bank is presented in Table 3. As on 31 December 2014, the banks maintained a total Tier 1 capital of SAR 26 Billion and the total eligible capital was SR 30.8 Billion. 
Table 3 Capital Structure of the Bank (as on 31 December 2014)

Source: Financial Report 2014-15

\begin{tabular}{|l|l|l|}
\hline & Components of Capital & SAR '000 \\
\hline $\mathbf{A}$ & Core Capital - Tier I & \\
\hline & Eligible paid-up share capital & $12,053,572$ \\
\hline & Statutory and general reserves & $9,919,264$ \\
\hline & Retained earnings & $3,905,557$ \\
\hline & Other reserves & 592,944 \\
\hline & Cash flow hedge reserve & $(98,159)$ \\
\hline & & \\
\hline $\mathbf{B}$ & TOTAL Tier 1 & $26,373,178$ \\
\hline & Supplementary Capital - Tier 2 & \\
\hline & Qualifying general provisions & $1,209,556$ \\
\hline & Subordinated Loan Capital & $3,216,000$ \\
\hline & & $\mathbf{3 0 , 7 9 8 , 7 3 4}$ \\
\hline & Total Eligible Capital (A+B) & \\
\hline
\end{tabular}

\subsection{Compliance with Basel III}

In order to assess the compliance of the bank with Basel III standards, the financial disclosures of the banks were examined. These reports were not audited by an external auditor. The Qualitative and Quantitative Disclosures regarding the Basel III form the main sources of information for the assessment. The summarized form of the compliance on all standards is presented in Table 4. The bank has been disclosing reports in accordance with Basel norms since 2008. In the current year 2015-16, the bank has published reports for three quarters. The bank separately publishes reports regarding Capital Structure, Liquidity Coverage Ratio and Leverage Ratio. The bank also publishes an annual report comprising of quantitative and qualitative disclosures. The main findings regarding the Bank's performance in terms of Basel III are listed below:

- The tier 1 capital as percentage of risk weighted assets was reported as $14.78 \%$. Tier 1 capital as on Sept 30, 2015 - 28,102,840. Basel III Leverage Ratio - 12.23\%

- The bank has started reporting the liquidity coverage ratio and leverage ratio from 2015 .

- The bank has allocated risk weights of $1250 \%$ and $250 \%$ to the significant minority investments that were deducted from $50 \%$ from tier 1 and $50 \%$ from tier 2 .

- The bank ensures that the transfer of dividend is done only after $25 \%$ of the net profit is transferred to the statutory reserves.

- The Risk Management Division of the bank is the department mainly responsible for the management of risks. The division plays a major role in policy formulation.

- The banks has applied a dedicated capital measurement system procured from a global vendor. The credit risk adjudication process is done at the central level.

- The Bank uses an internal rating methodology for classification of counterparty risk and in the management of the underlying exposures appropriately.

- The Bank also follows SAMA's guidelines for asset classification, particularly those relating to past due /non-performing loans.

- For the purpose of determining counterparty risk weights, the Bank uses external credit assessments from Standard and Poors, Moodys, and Fitch.

- The applicable financial collateral for credit risk mitigation under Basel III is restricted to pledge of cash margins and deposits held with the Bank. Guarantees used for risk transfer purposes are mainly bank guarantees that meet the requirements stipulated in the Accord.

- The Market Risk Department within the Risk Management Division is responsible for measurement and controls involved in management of market risks. Market risk activity at the bank is governed by the bank's Market Risk Committee which meets regularly, and is closely supervised by a dedicated Market Risk Department that reports independently to the bank's Chief Risk Officer.

- A comprehensive bank-wide Risk and Control assessment for risk identification

- There is an Operational Risk \& Permanent Control Department that studies the status of control implementation, areas of risk and required actions for various business entities to the Internal Control Committees. It is also the central repository for operational loss data of the Bank.

- The Bank has also implemented a robust Business Continuity Plan to ensure continuity of critical operations.

- Board Risk Committee at the Board level and Internal Control Committees at the executive level oversee bank wide implementation of Board approved policies and processes in this regard.

- The Bank's nature of the equity risk exposure includes: Investment in associates; Available for sale equity investment; Investment in subsidiaries. 
- The Bank has formulated a policy of transferring the interest rate risk positions from all business lines to central management. The short term positions are managed by the Bank's Treasury department and long term positions by the Asset \& Liability Management department

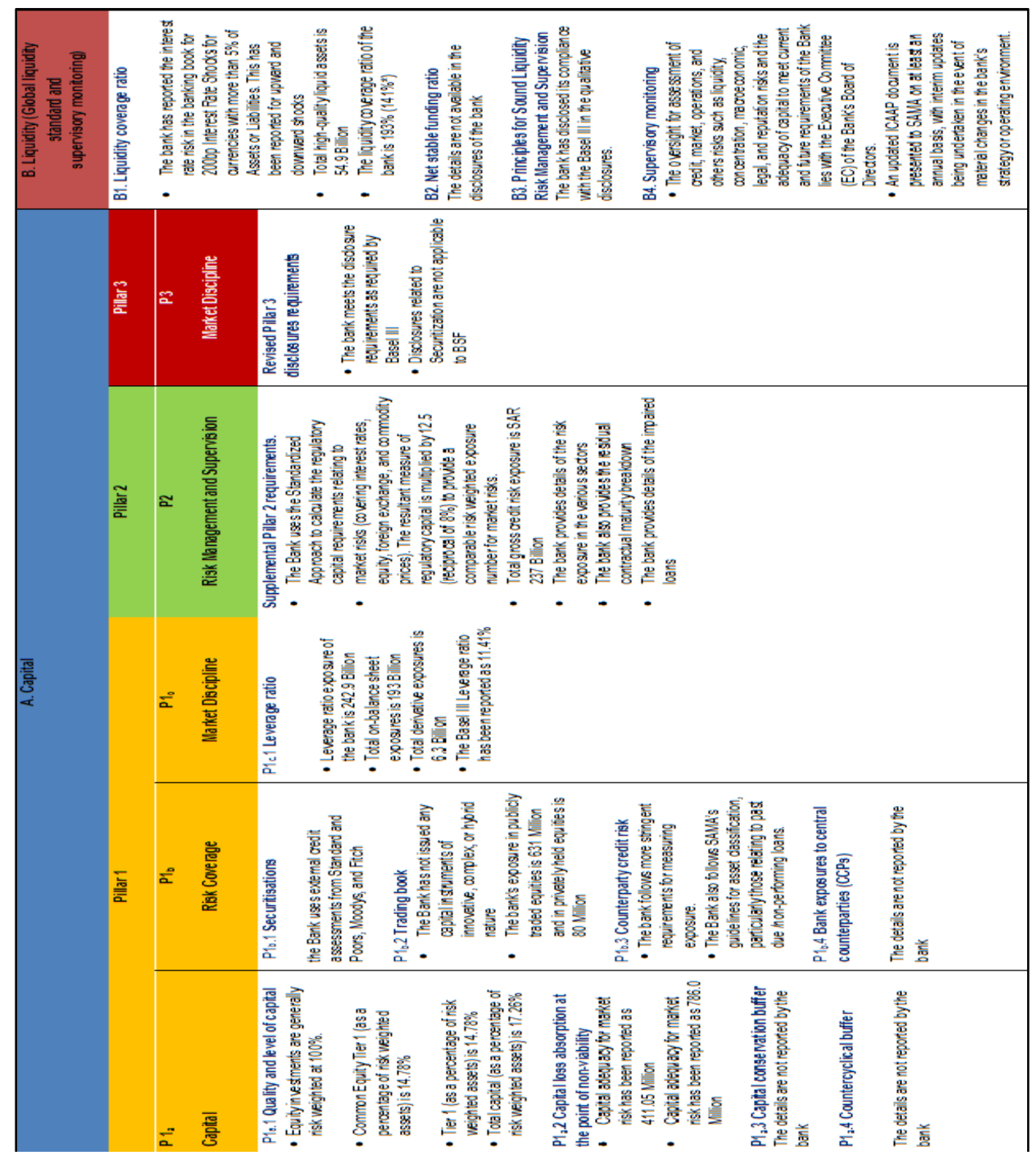

Figure 3 Summary of the compliance of Banque Saudi Fransi with Basel III

\section{Conclusion}

Saudi Arabia holds a significant position among the Gulf countries in the implementation of Basel III regulations. Saudi Arabian Monetary Agency being a member of the Basel Committee has been actively formulating framework for the full and timely implementation of Basel III by all the banks. the external assessments of the compliance indicate that the level of compliance is good. It is important to note that the implementation of Basel III will have significant impacts on the profitability of the banks. Another issue is the banks' resistance because the Arab Banks were not exposed to the risks that led to the financial crisis. therefore the banks are wary of being penalized for wrong done by others. The new norms are more complex and requires substantial intervention from both technology and procedural dimensions. Saudi Arabia was able to implement Basel II completely and the implementation of Basel III will require more synchronized efforts, continuous communication and feedback between SAMA and the banks. This study tried to check the compliance of the individual bank with Basel III. The results show that the bank has been actively implementing the new standards. However the limitation of the findings is complete reliance on the financial disclosures by the bank. At the next level of the study involving three banks, multiple sources of information will be analyzed to check the extent of compliance. Still, the results of this study are significant for the researchers and policy makers who are interested in finding the compliance of banks with Basel III in Saudi Arabia. 


\section{References}

[1]. SAMA 2011, Announcement of the Basel III Accord and SAMA Plans for its Implementation of Basel II and III in 2011. Available at http://www.sama.gov.sa/en-US/Laws/Documents/3. \%20SAMA\%20Basel\%20III\% 20Program/1.\%20Announcement\% 20of\% 20 the $\% 20$ Basel $\% 20 \mathrm{III} \% 20$ Accord $\% 20$ and $\% 20$ SAMA $\% 20$ Plans $\% 20$ for $\% 20$ its $\% 20$ Implementation $\% 20$ of $\% 20$ Basel $\% 20 \mathrm{II} \% 20$ and $\% 20 \mathrm{III} \% 20 \mathrm{in} \% 202011 . \mathrm{pdf}$

[2]. SAMA 2012, SAMAs Final Guidance document on Capital Reforms under Basel III Available at: http://www.sama.gov.sa/enUS/Laws/Documents/3.\%20SAMA\%20Base1\%20III\%20Program/2.\%20SAMAs\%20Final\%20Guidance\%20document $\% 20$ on $\% 20$ Capital\%20Reforms\%20under\%20Basel\%20III.pdf

[3]. SAMA 2004, Capital Adequacy Requirements for Market Risk. Available at: http://www.sama.gov.sa/en-US/Laws/ Documents/1. \%20SAMA\%20Basel\%20II\%20Program/1.\%20Capital\%20Adequacy\%20Requirements\%20for\%20Market\%20Risk.pdf

[4]. SAMA 2014, SAMAs Final document concerning Basel III IRB Approaches, Available at: http://www.sama.gov.sa/enUS/Laws/Documents/3.\%20SAMA\%20Basel\%20III\%20Program/4.\%20SAMAs\%20Final\%20document\%20concerning\%20Basel \%20III\%20IRB\%20Approaches.pdf

[5]. BIS 2011, Basel Committee - Final elements of the reform - Loss absorbency at the Point of Non-Viability. Available at: http://www.sama.gov.sa/en-US/Laws/Documents/3.\%20SAMA\%20Basel\%20III\%20Program/5.\%20Basel\%20Committee\%20\%20Final\%20elements\%20of\%20the\%20reform\%20-\%20Loss\%20absorbency\%20at\%20the\%20Point\%20of\%20NonViability.pdf

[6]. SAMA 2012, SAMAs Prudential Returns concerning the Monitoring of Basel III Liquidity Risk. Available at: http://www. sama.gov. sa/en-US/Laws/Documents/4. \%20SAMA\%20Liquidity\%20Standards \%20Program/1. \%20SAMAs\%20Prudential\% 20Returns\%20concerning\%20the\%20Monitoring\%20of\%20Base1\%20III\%20Liquidity\%20Risk.pdf

[7]. SAMA 2013, BCBS Document issued in April 2014 regarding Frequently Asked Questions on Basel IIIs January 2013. Available at: http://www.sama.gov.sa/en-US/Laws/Documents/4. \%20SAMA\%20Liquidity\% 20Standards\%20Program/6. \%20BCBS\% 20 Document $\% 20$ issued\%20in\%20April\%202014\%20regarding\%20Frequently\%20Asked\%20Questions\%20on\%20Basel\%20IIIs\%20 January\%202013.pdf

[8]. SAMA 2012, Quarterly Monitoring of Capital Leverage Ratio in 2011 and 2012. http://www.sama.gov.sa/en-US/Laws/ Documents/5.\%20SAMA\%20Leverage\%20Ratio\%20Program/1.\%20Quarterly\%20Monitoring\%20of\%20Capital\%20Leverage $\% 20$ Ratio\%20in\%202011\%20and\%202012.pdf

[9]. Basel Committee on Banking Supervision (2015). Capital treatment for "simple, transparent and comparable" securitizations, Consultative Document. Available at: http://www.bis.org/bcbs/publ/d343.pdf

[10]. Basel Committee on Banking Supervision 2014, Revisions to the securitization framework. Available at: http://www. bis.org/ bcbs/publ/d303.pdf

[11]. Basel Committee on Banking Supervision 2014, Implementation of Basel standards - A report to G20 Leaders on implementation of the Basel III regulatory reforms Available at: http://www.bis.org/bcbs/publ/d299.pdf

[12]. KPMG 2011, BASEL III: Issues and Implications. Available at: http://www. kpmg.com/global/en/ issuesandinsights/ articlespublications/documents/basell-iii-issues-implications.pdf

[13]. Hazarika, D. and Dubey,S, 2014 Dissecting Basel III by Geography, Cognizant Available at: http://www.cognizant. com/InsightsWhitepapers/dissecting-basel-iii-by-geography-codex945.pdf

[14]. Diemers, D., Gassmann, P. and Khalil, J. 2014, Basel III: A Silver Lining for Middle East Banks. Price Waterhouse Coopers. Available at: http://www.strategyand.pwc.com/media/file/Basel-III_A-silver-lining-for-Middle-East-banks.pdf

[15]. BIS 2015, Assessment of Basel III risk-based capital regulations - Saudi Arabia

[16]. KPMG 2011, Basel III: Issues and Implications.

[17]. BIS 2013, Basel III: International Framework for Liquidity Risk Measurement, Standards and Monitoring. 